\title{
East Slavic Language
}

National Cancer Institute

\section{Source}

National Cancer Institute. East Slavic Language. NCI Thesaurus. Code C161857.

A regional subgroup of the Slavic languages, currently spoken throughout Eastern

Europe, Northern Asia, and the Caucasus. 